\title{
Correction to: Ziying and Woods Hole: Bringing the Marine Biological Laboratory to Amoy, China, 1930-1936
}

\section{Christine Y. L. Luk ${ }^{1}$}

Accepted: 27 August 2021 / Published online: 9 September 2021

(c) The Author(s), under exclusive licence to Springer Nature B.V. 2021

\section{Correction to: Journal of the History of Biology https://doi.org/10.1007/s10739-021-09636-7}

In this article, on page 159, in the sentence beginning 'Between 1945 and 1949,...', the years '1945' and '1949' should have read '1938' and '1945'.

The correct sentence should read: Between 1938 and 1945, Amoy University was taken over by the Japanese navy and used as a base during the Pacific War.

The original article has been corrected.

Publisher's Note Springer Nature remains neutral with regard to jurisdictional claims in published maps and institutional affiliations.

The original article can be found online at https://doi.org/10.1007/s10739-021-09636-7.

Christine Y. L. Luk

chrisluk@tsinghua.edu.cn

1 Department of the History of Science, Tsinghua University, Room 511, Meng Min Wei Humanities Building, Beijing 10084, China 